Benjamin Hary, Sarah Bunin Benor (Eds.)

Languages in Jewish Communities, Past and Present 


\section{Contributions to the Sociology of Language}

Edited by

Ofelia García

Francis M. Hult

Founding editor

Joshua A. Fishman

Volume 112 


\section{Languages in Jewish Communities, Past and Present}

Edited by

Benjamin Hary

Sarah Bunin Benor

DE GRUYTER

MOUTON 
ISBN 978-1-5015-1298-8

e-ISBN (PDF) 978-1-5015-0463-1

e-ISBN (EPUB) 978-1-5015-0455-6

ISSN 1861-0676

\section{Library of Congress Cataloging-in-Publication Data}

Names: Benor, Sarah, 1975- editor. | Hary, Benjamin H., editor.

Title: Languages in Jewish communities : past and present / edited by

Benjamin Hary, Sarah Bunin Benor.

Description: First edition. | Berlin ; Boston : Walter De Gruyter, [2018] |

Series: Contributions to the Sociology of Language (CSL) ISSN 1861-0676 ;

112

Identifiers: LCCN 2018027142| ISBN 9781501512988 (print) | ISBN 9781501504556

(e-book (epub) | ISBN 9781501504631 (e-book (pdf)

Subjects: LCSH: Jews-Languages-History. | Sociolinguistics. |

Jews-Identity.

Classification: LCC PJ5061 .L35 2018 | DDC 408.9924-dc23 LC record available at

https://lccn.loc.gov/2018027142

\section{Bibliographic information published by the Deutsche Nationalbibliothek}

The Deutsche Nationalbibliothek lists this publication in the Deutsche Nationalbibliografie; detailed bibliographic data are available on the Internet at http://dnb.dnb.de.

(C) 2018 Walter de Gruyter Inc., Boston/Berlin

Typesetting: Integra Software Services Pvt. Ltd

Printing and binding: CPI books $\mathrm{GmbH}$, Leck

Cover image: sculpies/shutterstock

www.degruyter.com 
This book is dedicated to the last generations of those who speak endangered languages and to the new generations of those who speak thriving languages. May this volume spark intergenerational and international conversations and collaborations.

$$
\text { מכל מלמדיי השכלתי ומכל חבריי למדתי }
$$

From all my teachers I have benefited and from all my friends I have learned

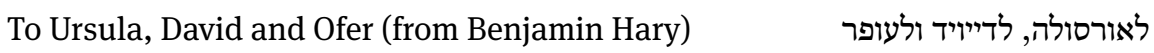

And to Solomon Birnbaum and Max Weinreich, pioneers of the field (from Sarah Bunin Benor) 
